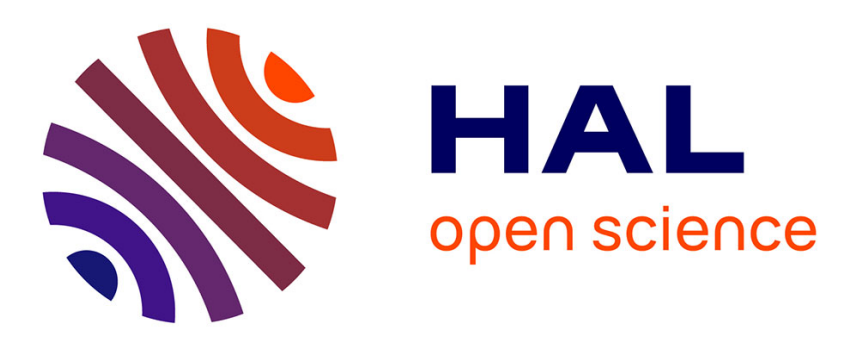

\title{
Treating enhanced GABAergic inhibition in Down syndrome: use of GABA alpha5-selective inverse agonists
}

Carmen Martinez-Cué, B. Delatour, M. C. Potier

\section{- To cite this version:}

Carmen Martinez-Cué, B. Delatour, M. C. Potier. Treating enhanced GABAergic inhibition in Down syndrome: use of GABA alpha5-selective inverse agonists. Neurosci Biobehav Rev, 2014, 46 Pt 2, pp.218-27. 10.1016/j.neubiorev.2013.12.008 . hal-03236876

\section{HAL Id: hal-03236876 \\ https://cnrs.hal.science/hal-03236876}

Submitted on 26 May 2021

HAL is a multi-disciplinary open access archive for the deposit and dissemination of scientific research documents, whether they are published or not. The documents may come from teaching and research institutions in France or abroad, or from public or private research centers.
L'archive ouverte pluridisciplinaire HAL, est destinée au dépôt et à la diffusion de documents scientifiques de niveau recherche, publiés ou non, émanant des établissements d'enseignement et de recherche français ou étrangers, des laboratoires publics ou privés. 
Title: Treating enhanced GABAergic inhibition in Down syndrome: use of GABA $\alpha 5$-selective inverse agonists.

Authors: Carmen Martínez-Cué ${ }^{1}$, Benoît Delatour ${ }^{2}$, and Marie-Claude Potier ${ }^{2 *}$

Affiliations: ${ }^{1}$ Department of Physiology and Pharmacology, Faculty of Medicine, University of Cantabria, Santander, Spain; ${ }^{2}$ Centre de Recherche de l'Institut du Cerveau et de Moelle Epinière, CNRS UMR7225, INSERM UMRS 975, UPMC, ICM, Hôpital Pitié-Salpêtrière, Paris, France.

\section{*Corresponding author:}

Dr. Marie-Claude POTIER

ICM

Hôpital Pitié-Salpêtrière

CNRS UMR7225, INSERM UMRS975, UPMC

47, Bd de l'Hôpital

75013 PARIS, FRANCE

$+33157274519$

marie-claude.potier@upmc.fr 


\begin{abstract}
Excess inhibition in the brain of individuals carrying an extra copy of chromosome 21 could be responsible for cognitive deficits observed throughout their lives. A change in the excitatory/inhibitory balance in adulthood would alter synaptic plasticity, potentially triggering learning and memory deficits. $\gamma$-aminobutyric acid (GABA) is the major inhibitory neurotransmitter in the mature central nervous system and binds to $\mathrm{GABA}_{\mathrm{A}}$ receptors, opens a chloride channel, and reduces neuronal excitability. In this review we discuss methods to alleviate neuronal inhibition in a mouse model of Down syndrome, the Ts65Dn mouse, using either an antagonist (pentylenetetrazol) or two different inverse agonists selective for the $\alpha 5$ subunit containing receptor. Both inverse agonists, which reduce inhibitory GABAergic transmission, could rescue learning and memory deficits in Ts65Dn mice. We also discuss safety issues since modulation of the excitatory-inhibitory balance to improve cognition without inducing seizures remains particularly difficult when using GABA antagonists.
\end{abstract}

Key words: Down syndrome, $\gamma$-aminobutyric acid, inverse agonist, $\alpha 5$-subunit containing $\mathrm{GABA}_{\mathrm{A}}$ receptor, convulsion, behavior. 


\section{INTRODUCTION}

Down syndrome (DS), resulting from trisomy of chromosome 21, is the most common genetic cause of intellectual disability (Lejeune et al., 1959; Bittles et al., 2007; Sherman et al., 2007). This disorder is associated with neurological complications including cognitive deficits that lead to mild to profound impairment in intellectual functioning (Lott \& Dierssen, 2010).

Some cognitive deficits have been alleviated by advances in teaching methods and educational mainstreaming, but these approaches are not sufficient to counteract all cognitive deficits (Wishart, 2007). Treatments aimed at enhancing cognitive skills to provide higher autonomy remain necessary. However, pharmacological treatments were dismissed as unlikely to improve cognition in DS because many neurotransmitter systems and brain circuits are affected from early developmental stages in this disorder.

Several murine models of DS have been developed in recent years. Studies of these models have provided significant insight on the neurobiological mechanisms underlying cognitive deficits in DS. In addition, they have proven to be useful in testing new pharmacological approaches to reduce DS-related cognitive impairments (Bartesaghi et al., 2011; Rueda et al., 2012). Indeed, recent studies in mouse models have suggested that affected brain circuits could be potential targets of pharmacotherapies to enhance cognitive deficits in the DS population (Fernandez et al., 2007; Costa et al., 2008; Rueda et al., 2008; Salehi et al., 2009; Faizi et al., 2011). In this way, mouse models can provide the pre-clinical basis for new treatments to emerge.

The best-characterized and most widely used model of DS is the Ts65Dn mouse. Ts65Dn has segmental trisomy of murine chromosome 16, containing 92 human orthologs between Mrp139 and Znf295 (Sturgeon \& Gardiner, 2011). This murine model recapitulates several fundamental features of DS including cognitive deficits and alterations in brain morphology and function (Bartesaghi et al., 2011; Haydar \& Reeves, 2012; Rueda et al., 2012). At the behavioral level Ts65Dn mice are hyperactive (Escorihuela et al., 1995; Reeves et al., 1995; Holtzman et al., 
1996), have developmental delay (Holtzman et al., 1996), and exhibit alterations in processes reduced attention (Escorihuela et al., 1998; Driscoll et al., 2004; Martinez-Cue et al., 2006; Rueda et al., 2012; Martinez-Cue et al., 2013). These cognitive deficits likely result, in part, from various neuromorphological alterations including changes in 1) the size, morphology, and cellular density of different brain areas; 2) pre- and post-natal neurogenesis; 3) dendritic structure; and 4) the morphology of synapses and spines (Bartesaghi et al., 2011; Rueda et al., 2012). Finally, abnormal synaptic plasticity, as shown by the reduction in long-term potentiation (LTP) in the hippocampal CA1 and dentate gyrus (DG) areas, also compromises the cognition of Ts65Dn mice (Siarey et al., 1999; Kleschevnikov et al., 2004).

\section{EXCESSIVE INHIBITION: A MAJOR FEATURE OF DS}

\subsection{Over-inhibition in DS}

One major functional defect observed in the brains of both individuals with DS and the Ts65Dn mouse model appears to be an imbalance between excitatory and inhibitory neurotransmission. In particular, excessive inhibition has been proposed as one of the underlying causes of the cognitive deficits in DS. Overinhibition can result from increased $\gamma$-aminobutyric acid (GABA) concentration at the synapse. Interestingly, however, several studies have shown either a decrease or no change in GABA concentration in individuals with DS compared with euploid individuals. Specifically, $60 \%$ less GABA was detected in the frontal cortex of fetuses with DS (Whittle et al., 2007). Similarly, decreased GABA was observed in temporal lobes, but not frontal lobes, of children with DS between 3 and 17 years old using in vivo magnetic resonance spectroscopy (MRS) (Smigielska-Kuzia \& Sobaniec, 2007; Smigielska-Kuzia et al., 2010). Further, the only MRS study of Ts65Dn mouse brain published to date could not identify the resonance peak corresponding to GABA (Huang et al., 2000).

Post-mortem studies of adults with DS and Alzheimer's disease (AD) neuropathology using radioassay chromatography showed that levels of GABA were globally unchanged in 
individuals with DS and AD (Seidl et al., 2001). However, a significant deficit of GABA was detected in the hippocampus and the temporal cortex of individuals with DS and neocortical neurofibrillary tangles. These results are consistent with losses of cortical neurons containing these neurotransmitters (Reynolds \& Warner, 1988). Together, these studies showing either a decrease or no change in GABA levels in fetuses, children, and adults with DS make it unlikely that over-inhibition in the brain of individuals with DS results from increased GABA concentrations.

Another potential explanation for altered inhibition in individuals with DS has been postulated. Brains of individuals with DS have fewer small, granular, (presumably) GABAergic neurons in layers II and IV of the cortex (Ross et al., 1984). In addition, microarray studies of human neural progenitor cells (hNPCs) in DS revealed gene expression changes indicative of defects in interneuron progenitor development that may lead to decreased GABAergic interneuron neurogenesis (Bhattacharyya et al., 2009).

Further information may be gained from ongoing studies aiming at quantifying the expression of GABA receptors. Positron Emission Tomography (PET) studies using either [ $\left[{ }^{11} \mathrm{C}\right]$ Ro15 4513 or $\left[{ }^{11} \mathrm{C}\right]$ flumazenil help measure in vivo $\mathrm{GABA}_{\mathrm{A}}$ receptor subtype occupancy, particularly for those containing the $\alpha 5$ subtype (Lingford-Hughes et al., 2002; Eng et al., 2010). A molecular and functional brain imaging study is ongoing in individuals with DS (NCT01667367).

\subsection{Over-inhibition in Ts65Dn mice}

Many studies have shown that cognitive impairment in the Ts65Dn mouse model is associated with excessive levels of neuronal inhibition. In particular, a recent study identified an increased number of inhibitory neurons in the forebrains of newborn Ts65Dn mice, paralleled by an increase in spontaneous inhibitory postsynaptic currents in the pyramidal neurons of the CA1 region due to overexpression of Olig1 and Olig2 (Chakrabarti et al., 2010). These mice also 
display fewer asymmetric synapses that mediate excitatory transmission in the temporal cortex and dentate gyrus (DG) (Kurt et al., 2004) and synaptic structural abnormalities in the hippocampus and cortex, including a selective reorganization of the inhibitory input (Belichenko et al., 2004; Perez-Cremades et al., 2010).

However, while overinhibition has been observed in some brain regions, the phenomenon may not represent all brain areas and may vary between cells and with age. Increases in $\mathrm{GABA}_{\mathrm{A}}$ receptor-mediated synaptic transmission occurs in CA1 neuron subtypes at specific times. Mitra et al. found that hippocampal neurons from Ts65Dn mice have significantly larger inhibitory responses when compared to age-matched controls at the end of the second postnatal week (P14-P16), but there was no significant difference in the amplitude of stimulus-evoked monosynaptic inhibitory post-synaptic potentials (IPSPs) at the end of the first (P8-P10) and third (P19-P21) postnatal weeks (Mitra et al., 2012). This transient change in evoked inhibition was observed only when stimulating the strata radiatum and pyramidale but not in the stratum oriens. In addition, hippocampal CA3 pyramidal neurons of newborn (P5) Ts65Dn mice have reduced inhibitory $\mathrm{GABA}_{\mathrm{A}}$ receptor-mediated synaptic input and no impairment in LTP (Hanson et al., 2007). Thus, while interneuron activity resulting from excitatory network impingement on interneurons is undiminished, intrinsic activity of interneurons in the absence of this excitatory drive is significantly reduced in Ts65Dn mice. Finally, in contrast to increased GABAergic inhibition in dentate granule cells and CA1 pyramidal neurons of Ts65Dn hippocampi, cerebellar granule cells show smaller tonic $\mathrm{GABA}_{\mathrm{A}}$ receptor currents (Szemes et al., 2013).

Gene expression profiles from the hippocampus revealed that GABA synthesis enzymes glutamate decarboxylase Gad-65 and Gad67 are expressed similarly in Ts65Dn mice and euploid controls (Braudeau et al., 2011a). However, increased levels of these synaptic proteins at hippocampal and cortical inhibitory synapses have been found. GAD65, GAD67, and the vesicular GABA transporter (VGAT) are increased in the brains of Ts65Dn mice (Perez- 
Cremades et al., 2010; Martinez-Cue et al., 2013). Moreover, a significant increase in colocalization of GAD65 and the vesicular GABA transporter was reported in the fascia dentate of Ts65Dn mice (Belichenko et al., 2009).

A wide array of studies has shown that the Ts65Dn mouse presents enhanced $\mathrm{GABA}_{\mathrm{A}}$ and $\mathrm{GABA}_{\mathrm{B}}$ mediated transmission. Specifically, overexpression of the Girk2 gene leads to a significant increase in $\mathrm{GABA}_{\mathrm{B}}$-mediated GIRK currents in hippocampal neuron cultures, which affects the balance between excitatory and inhibitory transmission (Best et al., 2007; Best et al., 2012). Recent studies demonstrated positive effects of $\mathrm{GABA}_{\mathrm{B}}$ receptor modulation for the treatment of cognitive impairments in DS (Kleschevnikov et al., 2012a; Kleschevnikov et al., 2012b). However, the $\mathrm{GABA}_{\mathrm{A}}$ receptor family is the predominant type in the brain and has a long history for modulating learning and memory functions.

Altogether these studies strongly suggest that $\mathrm{GABA}_{\mathrm{A}}$ receptors represent an important potential target in the population with DS.

\section{FIRST PHARMACOLOGICAL APPROACHES TO REDUCE INHIBITION}

The $\mathrm{GABA}_{\mathrm{A}}$ receptor system plays an important role in cognition. Non-selective positive allosteric modulators $(\mathrm{PAM})$ of the $\mathrm{GABA}_{\mathrm{A}}$ receptor disrupt learning and memory processes (Lister, 1985; Cole, 1986; Ghoneim \& Mewaldt, 1990). In contrast, non-selective negative allosteric modulators (NAM) improve cognitive processes (Jensen et al., 1987; Venault et al., 1987; Sarter et al., 2001; Venault \& Chapouthier, 2007). In addition, non-selective $\mathrm{GABA}_{\mathrm{A}}$ inverse agonists like DMCM increase LTP (Seabrook et al., 1997), while non-selective $\mathrm{GABA}_{\mathrm{A}}$ agonists (e.g., diazepam) impair LTP (del Cerro et al., 1992). Given the alterations of GABAmediated transmission in individuals with DS, pharmacological manipulation of this system has been applied in DS mouse models toward mitigating cognitive phenotypes.

In the Ts65Dn mouse, the marked reduction in LTP in the CA1 and DG areas of the hippocampus has been associated with enhanced GABA-mediated inhibition (Siarey et al., 1997; Belichenko et al., 2004; Kleschevnikov et al., 2004; Costa \& Grybko, 2005; Fernandez et 
al., 2007; Belichenko et al., 2009; Kleschevnikov et al., 2012a; Kleschevnikov et al., 2012b): impaired synaptic plasticity can be restored in the Ts65Dn mouse by administering the $\mathrm{GABA}_{\mathrm{A}}$ antagonist, picrotoxin (Kleschevnikov et al., 2004; Fernandez et al., 2007). In line with these findings, reducing inhibitory neurotransmission by chronic administration of non-selective $\mathrm{GABA}_{\mathrm{A}}$ receptor antagonists picrotoxin, bilobalide, or pentylenetetrazole (PTZ) reverses the deficits in LTP and hippocampal-mediated memory of Ts65Dn mice (Fernandez et al., 2007). A two-week daily regimen of these $\mathrm{GABA}_{\mathrm{A}}$ antagonists (picrotoxin, bilobalide, or PTZ) at low doses normalizes memory performance of 6-month-old Ts65Dn mice in the novel object recognition (NOR) task when they were tested either one week or 2 months after drug treatment. However, acute administration of PTZ ( $3 \mathrm{mg} / \mathrm{Kg}$ per os) did not improve cognitive performance in Ts65Dn mice. Further, pro-cognitive effects of chronic treatment (7 weeks) with PTZ in 4-month-old Ts65Dn mice were demonstrated in another hippocampal-dependent task: the Morris water maze (MWM), a spatial reference memory task (Rueda et al., 2008).

Such findings have led to further investigation of the efficacy of PTZ in mouse models. A recent study demonstrated that chronic, short-term, low-dose administration of PTZ elicits long-lasting (over 1 week) normalization of cognitive function, assessed in the NOR test, in young (2-3 months) and aged (12-15-month-old) Ts65Dn mice (Colas et al., 2013). Further, the treatment produces power normalization of the EEG anomalies found in untreated Ts65Dn mice (Colas et al., 2008). Altogether, these studies suggest that chronic PTZ administration (from 2 to 7 weeks) has a pro-cognitive effect in Ts65Dn mice at different ages.

Some contradictory findings on the effects of PTZ administration in Ts65Dn mice have been reported. Colas et al. stated that the efficacy of PTZ is associated with nycthemeral contingencies (Colas et al., 2013). In that study, Ts65Dn mice performed better in the NOR task when PTZ was delivered during the light (inactive) phase, not during the dark (active) phase. However, in our study, PTZ was administered one hour before all behavioral tests, which were performed in the middle of the active phase (Rueda et al., 2008). Under these conditions, 
cognitive deficits of Ts65Dn mice were completely rescued (as measured by MWM). These or may indicate cognition enhancement by two different, non-exclusive mechanisms. While Colas et al. trained the animals for two weeks and tested their cognitive abilities one week later, we tested mice one hour after each administration of PTZ. Therefore, the differential effects found in both studies when the drug was administered during the dark phase of the cycle suggest that the pro-cognitive effect of this $\mathrm{GABA}_{\mathrm{A}}$ antagonist might be symptomatic (with PTZ having direct pro-cognitive effects when present at the receptor, regardless of time of the day in which it was administered) and/or might induce a long-lasting reorganization of different neuronal circuits, in which the time of the day might be determinant (Colas et al., 2013). (See below for a discussion between symptomatic vs. long-lasting effects). Notably, PTZ treatment did not induce any significant pro-cognitive effect in control mice, although a trend was found after long-term evaluation (Fernandez et al., 2007).

Despite the apparent pro-cognitive effect of PTZ in different experimental conditions in DS models, this drug has not been an adequate candidate for the treatment of learning impairments in the DS population because of its known liabilities. Although $\mathrm{GABA}_{\mathrm{A}}$ receptor antagonists and NAMs show beneficial activity against impaired cognition, further clinical development of these compounds has been prevented by anxiogenic or pro-convulsive side effects (Dorow et al., 1983; Petersen et al., 1983; Little et al., 1984; Jensen et al., 1987; Venault et al., 1987; McNamara et al., 1993; Duka et al., 1996; Venault \& Chapouthier, 2007). However, the recent study by Colas et al. (2013) suggests that PTZ administration can be safe at cognitive-enhancing doses. Though convulsive at high doses (>30 mg/Kg in mice), such doses are $10-1000$-fold higher than those required for successful pharmacotherapy in Ts65Dn mice $(0.03-3 \mathrm{mg} / \mathrm{kg}-1)$. However, individuals with DS are more prone to convulsions (Menendez, 2005); seizures may affect as much as 6-17\% of the population (Veall, 1974), with a triphasic distribution of seizure onset depending on age (infancy, early adulthood, and late onset) (Pueschel et al., 1991). The 
ongoing clinical trial (http://compose21.com/study.htm) that assesses the safety and potential efficacy of PTZ in people with DS will clarify this point.

Importantly, Ts65Dn mice do not have an increased susceptibility to convulsions (Braudeau et al., 2011b); therefore, this model may not be most suitable for analyzing the putative proconvulsant effects of this drug. Future studies should assess whether other mouse models of DS present the phenotype of increased seizure susceptibility and evaluate the pro-convulsant effects of PTZ in these animals. Further, anxiogenic effects need to be closely investigated under conditions of chronic treatment with PTZ, to ensure its safety particularly for the DS population.

\section{THERAPEUTIC APPROACHES TARGETING $\alpha 5$-SUBUNIT-CONTAINING GABA $_{\mathrm{A}}$ RECEPTORS}

The $\mathrm{GABA}_{\mathrm{A}}$ receptor contains an intrinsic ligand-gated $\mathrm{Cl}^{-}$channel, formed by the pentameric assembly of different subunits $(\alpha 1-6, \beta 1-4, \gamma 1-3, \delta, \varepsilon, \theta$, and $\pi$ subunits) (Olsen et al., 1990; Macdonald \& Olsen, 1994; Rabow et al., 1995; Mohler et al., 1996; Bonnert et al., 1999; Whiting et al., 1999). The identification of different functions of $\mathrm{GABA}_{\mathrm{A}}$ receptor subtypes over the last decade suggests that receptor subtype-selective compounds could avoid the limitations of classical modulators of the $\mathrm{GABA}_{\mathrm{A}}$ receptor.

Among the $\mathrm{GABA}_{\mathrm{A}}$ receptor subtypes, $\mathrm{GABA}_{\mathrm{A}} \alpha 5$ subunit-containing receptors have been shown to play a modulatory role in cognition. $\alpha 5$ subunit-containing $\mathrm{GABA}_{\mathrm{A}}$ receptors are predominantly expressed in the hippocampus both in rodents and humans (Laurie et al., 1992; Fritschy \& Mohler, 1995; Lingford-Hughes et al., 2002; Klausberger, 2009; Olsen \& Sieghart, 2009). They are concentrated in the dendrites of hippocampal CA1 pyramidal neurons and play a role in regulating tonic inhibition through extrasynaptic receptors (Caraiscos et al., 2004); They have also been detected at GABAergic synapses on the dendrites of hippocampal pyramidal neurons where they could modulate phasic GABAergic inhibition (Serwanski et al., 2006). The role of these receptors in cognition has been demonstrated using mutant mice and 
subtype-selective ligands (Collinson et al., 2006; Dawson et al., 2006; Ballard et al., 2009) . In particular, mice with a partial deficit of $\alpha 5$-containing $\mathrm{GABA}_{\mathrm{A}}$ receptors in the hippocampus display an improved performance in trace fear conditioning (Crestani et al., 2002; Yee et al., 2004), and mice lacking the $\alpha 5$ subunit $\left(\alpha 5^{-1}\right)$ show an improved performance in the Morris water maze (Collinson et al., 2002).

These results generated the hypothesis that $\alpha 5$-containing $\mathrm{GABA}_{\mathrm{A}}$ receptors may represent a valuable target for memory-enhancing drugs, and several pharmaceutical companies developed $\alpha 5$-selective NAMs. Among these novel $\alpha 5$-selective NAMs are PWZ-029 (Savic et al., 2008), a triazolophtalazines $\alpha 5$ inverse agonist ( $\alpha 5$ IA) from Merck laboratories (Chambers et al., 2004; Sternfeld et al., 2004; Collinson et al., 2006; Dawson et al., 2006), and the triazolobenzodiazepine RO4938581/RG1662, from Hoffmann-La Roche (Ballard et al., 2009).

The $\quad \alpha 5 \mathrm{IA} \quad$ (3-(5-Methyllisoxazol-3-yl)6[(1-methyl-1,2,3-triazol-yl)methyl-oxy]-1,2,4triazolo[3,4,- $\alpha$ ]fthalazine) molecule is a negative allosteric modulator of GABAergic transmission. It has a higher efficacy at the $\alpha 5$ subunit as compared to the $\alpha 1$ subunit and is a weak positive allosteric modulator of the $\alpha 2$ and the $\alpha 3$ subunit-containing receptors; binding affinities are very similar for all subunits (Table 1) (Sternfeld et al., 2004). Chronic administration of $\alpha 5 \mathrm{IA}$ increases hippocampal LTP and cognition in the MWM without producing anxiogenic or pro-convulsant effects in rodents (Dawson et al., 2006). Interestingly, a5IA was able to reverse memory deficits induced by alcohol consumption in a small study involving human volunteers without showing signs of anxiogenesis (Nutt et al., 2007; Atack, 2010). Braudeau et al. failed to find any anatomopathological alterations in various organs from chronically-treated a5IA mice at high dosage (Braudeau et al., 2011b). Additionally, no apparent toxicity was reported in monkeys and humans (Atack, 2010). However, the hydroxylated metabolite M1 detected in rat kidneys was insoluble in in vitro tests when the metabolite was added to human urine as a powder. Although this is the only report to date, the authors concluded that there is a "significant overlap between urine concentration of M1 in vivo 
following the highest oral administration of the parent drug and M1 solubility measured in vitro" and that this metabolite might induce nephrotoxicity at very high doses (Merschman et al., 2005). Administration of $\alpha 5$ IA to humans over prolonged periods of time therefore remains difficult to justify (Mohler, 2012).

In contrast, RO4938581 (3-bromo-10-(difluoromethyl)-9H-benzo[f]imidazo[1,5a][1,2,4]triazolo[1,5-d][1,4]diazepine) has a higher affinity for the $\alpha 5$-containing $\mathrm{GABA}_{\mathrm{A}}$ receptors than for the $\alpha 1, \alpha 2$, and $\alpha 3$-containing $\mathrm{GABA}_{\mathrm{A}}$ receptors and is a NAM of $\alpha 5$ containing $\mathrm{GABA}_{\mathrm{A}}$ receptors only (Ballard et al., 2009) . The dual binding and functional selectivity of RO4938581 confer an ideal profile for cognition-enhancing effects without the unwanted side effects associated with activity at other $\mathrm{GABA}_{\mathrm{A}}$ receptor subtypes (Table 1).

In rodents, chronic RO4938581 treatment reverses scopolamine-induced working memory impairment in the delayed matched to position (DMTP) task and diazepam-induced spatial learning impairment in the MWM (Ballard et al., 2009). In addition, RO4938581 improves prefrontal-mediated executive function (object retrieval task) in cynomolgus macaques (Ballard et al., 2009). Importantly, RO4938581 did not show any anxiogenic or pro-convulsant activity. In addition, in rat hippocampal slices, RO4938581 modulated GABAergic inhibition of CA1 pyramidal cells and induced early LTP from a subthreshold tetanic stimulation paradigm in mouse hippocampal slices (Ballard et al., 2009) .

Consistent with the behavioral phenotype of $\alpha 5^{-/-}$mice (Collinson et al., 2002), both selective $\mathrm{GABA}_{\mathrm{A}} \alpha 5$ NAMs have cognition-enhancing effects without anxiogenic or pro-convulsant side effects associated with the activity of other subtypes of $\mathrm{GABA}_{\mathrm{A}}$ receptors (Chambers et al., 2004; Sternfeld et al., 2004; Atack et al., 2006; Collinson et al., 2006; Dawson et al., 2006; Rudolph \& Mohler, 2006; Nutt et al., 2007; Ballard et al., 2009; Braudeau et al., 2011b). A comparison of the two lead compounds ( $\alpha 5 \mathrm{IA}$ and RO4938581) in the same paradigms would be necessary to identify putative differences in their behavioral effects. 
MRK-016, a derivative of $\alpha$ IIA that could not be hydroxylated, functions as a cognition enhancer without any pro-convulsant or anxiogenic effects in animals (Atack, 2010). Unfortunately, the pharmacokinetics of this backup compound were not optimal, and the whole program was stopped by Merck before a new lead compound could be identified.

A further delineation of the role of $\alpha 5$-containing $\mathrm{GABA}_{\mathrm{A}}$ receptors in cognitive processes in humans is needed.

\subsection{Effects of $\alpha 5$-selective NAMS in Ts65Dn mice}

\subsubsection{Cognitive-enhancing effects}

Recently, two studies have evaluated the effects of $\alpha 5$ IA and RO4938581 on the cognitive deficits of Ts65Dn mice. Braudeau et al. showed that acute treatment (single $5 \mathrm{mg} / \mathrm{kg}$ i.p. dose, 30 minutes before each training session) with $\alpha 5$ IA restores learning and memory deficits of Ts65Dn mice in the MWM (Braudeau et al., 2011b). In this experimental setting where mice were trained for 6 days, $\alpha 5$ IA enhanced learning during the acquisition sessions, as well as reduced thigmotactic behavior, indicating an improvement in platform searching strategy. However, $\alpha 5$ IA did not rescue the altered retention of the platform position shown by Ts65Dn mice during the probe trial. In this study, $\alpha 5$ IA also rescued recognition memory in the novel object paradigm (Table 2).

Chronic oral administration of RO4938581 $(20 \mathrm{mg} / \mathrm{kg})$ has also been recently shown to have promnesic effects in the MWM (Martinez-Cue et al., 2013). These authors used two different protocols to assess working and reference spatial learning. During the first 8 sessions the platform position was changed every day to assess trial-dependent learning (i.e., spatial working memory). In sessions 9 to 12 , the platform was placed in the same location (standard protocol) to assess trial-independent spatial learning. After the last acquisition session, a probe trial was performed to evaluate memory of the platform position (spatial memory). Chronic treatment with RO4938581 significantly improved Ts65Dn mouse performance in the acquisition 
sessions, indicating rescue of both working and reference spatial learning. In contrast to the aforementioned study with $\alpha 5$ IA, RO4938581 also rescued memory of the platform position. These differential effects are likely due to differences in the training protocols between studies. In the RO4938581 study, mice performed a larger number of trials per day (8, vs. 2 trials per day in the $\alpha 5$ IA study). However, differences in the relative efficacy of both NAMs in restoring different cognitive processes cannot be excluded. Finally, consistent with the thigmotacticreducing effect of a5IA (Braudeau et al., 2011b), RO4938581 also reduced the enhanced thigmotaxis displayed by Ts65Dn mice in the hidden and visible platform tasks of the MWM, indicating that both drug treatments improved navigation strategies (Table 2).

Notably, both studies showed the ability of the two NAMs to improve the cognitive performance of euploid mice, with some variations depending on the drug used. RO4938581 failed to improve the cognitive performance of euploid mice in the MWM. These results are in agreement with another study (Ballard et al., 2009), which did not find any improvement in working memory in control rats in the DMTP task or in the MWM after chronic RO4938581 treatment. $\alpha 5$ IA also failed to improve the cognitive performance of euploid mice during the acquisition sessions of the MWM (Braudeau et al., 2011b). The lack of effect of both NAMs on the performance of euploid animals in the different versions of the MWM might be attributable to a ceiling effect. Interestingly, RO4938581 improved performance of cognitively typical monkeys in the object retrieval task. These animals were exposed to the task infrequently to prevent asymptotic performance, thus allowing a window for improvement (Ballard et al., 2009).

In contrast to RO4938581, $\alpha 5$ IA increased cognitive performances in the DMTP task in normal rats (Dawson et al., 2006). Consistent with these results, Braudeau et al. showed a cognitiveenhancing effect of $5 \mathrm{mg} / \mathrm{kg}$ of $\alpha 5 \mathrm{IA}$ in the DMTP task and in the NOR test in euploid animals (Braudeau et al., 2011b). Testing RO4938581 in the NOR task is an important next step to compare "side by side" the behavioral profile of both molecules. Also, to get a complete 
overview of the rescuing effects of NAMs in behaviorally-impaired Ts65Dn mice, it might be informative to evaluate the efficacy of the two drugs in non-spatial, hippocampal-dependent tasks such as fear contextual conditioning (Contestabile et al., 2012) and, more generally, in a standardized neuropsychological battery assessing various memory systems and related behavioural functions (Faizi et al., 2011).

Overall, data from the literature indicate that $\alpha 5$-selective NAMs can, to some extent, enhance cognition in euploid animals and can also rescue numerous compromised phenotypes in cognitively-impaired Ts65Dn mice. Therefore, these compounds warrant further investigation.

\subsubsection{Side effects}

\subsubsection{Convulsions}

Braudeau et al. (2011b) demonstrated that $\alpha 5$ IA has neither convulsant nor pro-convulsant activity in euploid or Ts65Dn mice. Simlarly, RO4938581 did not induce convulsions in euploid or Ts65Dn mice after chronic treatment or when administered at a dose 3 -fold higher than that used in the chronic study (Martinez-Cue et al., 2013).

\subsubsection{Hyperactivity}

Consistent with earlier studies that demonstrated hyperactivity in Ts65Dn mice (Escorihuela et al., 1995; Coussons-Read \& Crnic, 1996), increased locomotor activity of the Ts65Dn mouse in the open-field test was not modified after RO4938581 or a5IA treatment (Braudeau et al., 2011b; Martinez-Cue et al., 2013). However, RO4938581 reduced Ts65Dn mouse hyperactivity in the plus-maze and hole-board tests (Table 2). It has been proposed that the hyperactivity shown by Ts65Dn mice in situations that usually require caution/risk assessment and concomitant suppression of activity (Escorihuela et al., 1995; Coussons-Read \& Crnic, 1996; Martinez-Cue et al., 2006) is attributable to a reduced attention to potentially dangerous stimuli. Therefore, the reduced hyperactivity induced by $\alpha 5$ IA and R04938581 presumably ameliorated the attention deficits observed in Ts65Dn mice. 


\subsubsection{Anxiety}

RO4938581 did not induce anxiety in the open-field and plus-maze tasks. On the contrary, chronic treatment with this compound had an anxiolytic-like effect as it increased the number of crossings performed by euploid mice in the center of the open field. In the plus maze, while RO4938581 did not affect the motor components of anxiety, it reduced the cognitive components of anxiety as indicated by the lower number of risk assessment behaviors performed by chronically-treated Ts65Dn and euploid mice, indicating that this NAM has a slight anxiolytic effect (Martinez-Cue et al., 2013).

Vehicle-treated Ts65Dn mice spent more time in the open arms of the plus-maze, underlining some hypo-anxious/disinhibition traits and/or attention deficits in the Ts65Dn mice (Braudeau et al., 2011b). After administering a single dose of $\alpha 5 \mathrm{IA}(15 \mathrm{mg} / \mathrm{kg}, 3$-fold higher than the active dose in MWM or NOR), Ts65Dn and euploid mice performed equally, indicating that a5IA does not induce anxiogenic activity but rather normalizes the performance of Ts65Dn mice in the elevated plus-maze. In addition, chronic injection of $\alpha 5 \mathrm{IA}(5 \mathrm{mg} / \mathrm{kg}) 5$ times a week did not induce any effects on anxiety-related behaviors in euploid and Ts65Dn mice. Moreover, a5IA was shown to induce no anxiogenic effects in a phase 1 study in humans at $2 \mathrm{mg} / \mathrm{kg}$, corresponding to $50 \%$ occupancy of $\alpha 5$-containing $\mathrm{GABA}_{\mathrm{A}}$ receptors (Atack, 2010; Eng et al., 2010) (Table 2).

\subsubsection{Other side effects}

RO4938581 did not modify the sensorimotor abilities, motor coordination in the rotarod, or the amount of spontaneous activity in Ts65Dn or euploid mice. These results agree with a report (Ballard et al., 2009) showing that RO4938581 did not induce CNS side effects, differentiating it from non-selective negative modulators that are known to have a poor side effect profile (Dorow et al., 1983). Although a5IA has not been assessed for motor coordination deficits in 
Ts65Dn mice, it did not induce any side effects on motor coordination in euploid mice (Dawson et al., 2006).

\subsection{Mechanisms involved in NAM-induced enhanced cognition}

\subsubsection{Rescue of synaptic plasticity}

Hippocampal-mediated cognitive processes involve long-term changes in synaptic efficacy such as LTP. Chronic treatment with RO4938581 completely rescued the LTP deficit of Ts65Dn mice and also tended to enhance the induction of LTP in euploid mice. Previous studies showed that RO4938581 and $\alpha 5$ IA enhanced LTP after acute treatment of mouse hippocampal slices (Collinson et al., 2006; Dawson et al., 2006; Ballard et al., 2009). a5 subunit-containing $\mathrm{GABA}_{\mathrm{A}}$ receptors, predominantly localized extrasynaptically, mediate tonic inhibition (Glykys \& Mody, 2006) and regulate the excitability of hippocampal pyramidal neurons by influencing the strength of depolarization required to generate an action potential (Bonin et al., 2007). These results provide further evidence for a major role of $\mathrm{GABA}_{\mathrm{A}} \alpha 5$ receptors in the modulation of long-term synaptic plasticity and suggest that this may be a mechanism whereby RO4938581 treatment rescues cognitive deficits in Ts65Dn mice.

\subsubsection{Neurogenesis}

Alterations in hippocampal morphology, such as reductions in granule cell density and hippocampal neurogenesis, have been implicated in the cognitive deficits of Ts65Dn mice (Insausti et al., 1998; Rueda et al., 2005; Clark et al., 2006; Bianchi et al., 2010a; Bianchi et al., 2010b).

Because $\mathrm{GABA}_{\mathrm{A}}$ receptor activity is known to regulate neuronal proliferation, migration, differentiation, and integration of newly generated neurons (Tozuka et al., 2005; Ge et al., 2006; Earnheart et al., 2007), normalization of GABAergic activity after NAM administration could reduce these neuromorphological alterations and, thereby, enhance cognition. 
Chronic administration of RO4938581 fully restored the density of both proliferating cells and of mature granule cells in the dentate gyrus of Ts65Dn mice. Since both newborn and mature neurons are implicated in hippocampus-dependent learning and memory, the restoration of proliferation and of the density of mature neurons likely contribute to the cognition-enhancing effects of RO4938581 in Ts65Dn mice. A recent study showed that restoring neurogenesis by early treatment with fluoxetine or lithium is indeed accompanied by a recovery in the cognitive alterations found in Ts65Dn mice (Bianchi et al., 2010a; Contestabile et al., 2012).

\subsubsection{GABAergic synapses}

In line with enhanced GABA-mediated inhibition observed in Ts65Dn mice, Martínez-Cué et al. found that the increased density of the GABAergic synapse markers GAD65, GAD67, and VGAT in the molecular layer of the hippocampus of Ts65Dn mice was normalized by chronic RO4938581 administration (Martinez-Cue et al., 2013). Increased immunoreactivity of proteins associated with GABAergic synapses including GAD67, VGAT, GABA $A_{A}$ receptor-associated protein (GABARAP), and neuroligin 2 was measured previously in the neocortex and hippocampus of Ts65Dn mice (Belichenko et al., 2009; Perez-Cremades et al., 2010). Because several studies have shown that Ts65Dn mice display morphological and functional alterations in inhibitory circuitries in the hippocampus and cerebral cortex (Belichenko et al., 2004; Belichenko et al., 2009; Chakrabarti et al., 2010; Perez-Cremades et al., 2010; Begenisic et al., 2011), it is possible that RO4938581 rescues cognitive deficits in Ts65Dn mice by normalizing the number and/or function of inhibitory synapses and, therefore, re-establishes circuit inhibitory/excitatory balance and neuroplasticity.

\subsubsection{Receptors}

Similar density and distribution of $\mathrm{GABA}_{\mathrm{A}} \alpha 5$ receptors are found in Ts65Dn and euploid mice (Martinez-Cue et al., 2013). In addition, levels of $\mathrm{GABA}_{\mathrm{A}} \alpha 5$ receptor occupancy do not differ in the hippocampus of RO4938581-treated Ts65Dn and euploid mice. Expression of $\mathrm{GABA}_{\mathrm{A}}$ $\alpha 5$ receptors as well as in vivo binding of RO4938581 to $\mathrm{GABA}_{\mathrm{A}} \alpha 5$ receptors in Ts65Dn 
versus euploid mice were analyzed by ex vivo autoradiography performed after intravenous injection of the well-characterized $\mathrm{GABA}_{\mathrm{A}} \alpha 5$ subtype preferring radioligand $\left[{ }^{3} \mathrm{H}\right]-\mathrm{RO} 0154513$ (Sieghart et al., 1987). The quantitative analysis of the ex vivo autoradiograms for the baseline condition did not give any indication of different levels of $\mathrm{GABA}_{\mathrm{A}} \alpha 5$ expression in Ts65Dn mice compared to controls (Martinez-Cue et al., 2013).

The expression of three $\mathrm{GABA}_{\mathrm{A}}$ receptors subunits is altered in neural progenitor cells from individuals with DS: $\alpha 2$ is up-regulated, while $\alpha 5$ and $\beta 3$ subunits are down-regulated (Bhattacharyya et al., 2009). Other published microarray data did not reveal changes in $\mathrm{GABA}_{\mathrm{A}}$ receptor subunit expression (Saran et al., 2003; Braudeau et al., 2011a). Recently, Szemes et al. (2013) found a specific decrease of the $\beta 3 \mathrm{GABA}_{\mathrm{A}}$ subunit transcripts in granule cells of the cerebellum using single-cell reverse-transcription PCR.

In the Ts65Dn mouse, a significant decrease in expression of the $\mathrm{GABA}_{\mathrm{A}}$ receptor $\beta 2 / 3$ subunit has been reported in the DG early in development; this phenomenon is followed by a significant increase in months 3-8. Although no significant changes have been found for the $\beta 1$ subunit, an alteration in the ratio of $\beta 2 / 3$ to $\alpha 1$ is evident in the hippocampus of 3-month-old Ts65Dn mice (Belichenko et al., 2009), suggesting an increase in inhibitory neurotransmission with aging. In another recently published study, no change in $\mathrm{GABA}_{A}$ and $\mathrm{GABA}_{B}$ receptors could be identified (Kleschevnikov et al., 2012b); however, a 20\% decrease in $\mathrm{GABA}_{\mathrm{A}} \beta 2$ and $\beta 3$ proteins is observed in the DG of adult Ts65Dn mice (Belichenko et al., 2009).

Together, these findings suggest that changes in $\mathrm{GABA}_{\mathrm{A}} \alpha 5$ receptor density or occupancy after RO4938581 treatment are unlikely to be implicated in the cognitive enhancing effects of this drug.

4.2.5. Changes in gene expression after chronic treatment with $\alpha 5 \mathrm{IA}$ 
To gain insight into the mode of action of $\alpha 5 \mathrm{IA}$, Braudeau et al. investigated the expression of stimulation (Braudeau et al., 2011a; Braudeau et al., 2011b). The fos protein is classically used to map evoked neuronal activity (Tischmeyer \& Grimm, 1999; Guzowski et al., 2005). They showed that, in both Ts65Dn and euploid mice, fos translation triggered by a behavioral episode (exploration of a new environment) is strongly increased after treatment with $\alpha 5 \mathrm{IA}$ in the cortex and the CA1 region of the hippocampus but not in the DG, which lacks a high density of $\alpha 5-$ containing $\mathrm{GABA}_{\mathrm{A}}$ receptors. They then established gene expression profiles of Ts65Dn and euploid hippocampi collected after chronic treatment (12 days) with $\alpha 5$ IA and compared expression levels to vehicle-treated mice. Three triplicated genes were found to be differentially expressed between Ts65Dn and euploid mice; among them, the superoxide dismutase 1 (Sodl) gene has been shown to contribute to several clinical features of DS (Braudeau et al., 2011a). Interestingly, $\alpha 5$ IA treatments corrected the elevated levels of Sod1 seen in Ts65Dn mice.

In euploid mice, chronic treatment with $\alpha 5$ IA increased IEG expression, particularly of $c$-Fos and the activity-regulated cytoskeleton-associated protein (Arc) genes. In Ts65Dn mice, deficits in IEG activation, particularly of $c$-Fos and early growth response 2 (Egr2), were rescued after treatment with $\alpha 5$ IA but did not reach the levels obtained after $\alpha 5$ IA treatment in euploid mice. At the protein level no deficits of fos basal levels were identified between Ts65Dn and euploid mice.

Increased $\alpha 5$-induced activation of IEGs could allow a more efficient storage of information during memory processing and even correct deficits in learning and memory functions that have been described in DS.

\subsubsection{Symptomatic vs. long-term effects}

To understand the mechanisms by which the different non-selective and $\alpha 5$-selective NAMs of the $\mathrm{GABA}_{\mathrm{A}}$ receptors exert their pro-cognitive action, it is crucial to unravel whether their effects are short-term symptomatic (i.e., these drugs compensate the imbalance between 
excitation and inhibition acutely) and/or whether long-term changes in neuronal circuits are exerted. Numerous studies have shown that enhancing effects of $\mathrm{GABA}_{\mathrm{A}}$ antagonists (including PTZ) on memory in rodents requires that the drug be administered shortly before or after training (Krivanek \& McGaugh, 1968; Krivanek, 1971). Colas et al. (2013) found that the acute doses of PTZ administered $10 \mathrm{~min}$ before training enhanced long-term memory in young Ts65Dn mice but that this effect was not long-lasting. However, they did not find a procognitive effect of an acute single dose of PTZ given one day before training (Fernandez et al., 2007). Rueda et al. showed a cognitive-enhancing effect of PTZ administered 1 hour before testing in Ts65Dn mice; however, these authors did not test whether the changes were longlasting (Rueda et al., 2008).

Similar results have been reported using $\alpha 5$-selective NAMs. $\alpha 5$ IA facilitates memory performance during encoding but not during consolidation (i.e., between acquisition and retrieval) (Collinson et al., 2006). An acute treatment with $\alpha 5$ IA before training improved recognition memory in Ts65Dn mice (Braudeau et al., 2011b). In addition, chronic treatment with RO4938581 (administered 1 hour before daily training sessions) also rescued the learning deficits of Ts65Dn mice (Martinez-Cue et al., 2013). However, none of these studies evaluated whether the cognitive enhancing effect was maintained after the discontinuation of the drug administration.

Pro-cognitive effects of PTZ have been reported for Ts65Dn mice up to two months after discontinuation of the drug administration (Fernandez et al., 2007; Colas et al., 2013). Because this drug half-life is less than five hours, these authors propose that chronic PTZ therapy leads to a long-lasting circuit adaptation or reduced the GABA sensitivity of key circuits involved in learning and memory. Analysis of the putative mechanisms involved in this promnesic effect of the $\alpha 5$-selective NAMs in Ts65Dn mice indicates that morphological and plasticity changes (i.e., normalization of LTP, neurogenesis, granule cell density, of GABAergic synapse markers, and changes in IEGs expression) indeed occur after treatment. Thus, it remains possible that 
$\mathrm{GABA}_{\mathrm{A}}$ antagonists and NAMs exert their pro-cognitive effects by two mechanisms: compensating the imbalance between excitation and inhibition when administered acutely, and inducing long-term reorganization of circuits or the restoration of different neuromorphological anomalies found in Ts65Dnmice when chronically administered. Importantly, it remains to be shown whether morphological and neurogenesis changes are found after acute treatment with NAMs.

The deficit in GABA-mediated synaptic plasticity can contribute to different structural and morphological changes since neuronal proliferation and development (migration, differentiation, and integration of newly generated neurons) is regulated by $\mathrm{GABA}_{\mathrm{A}}$ (Tozuka et al., 2005; Ge et al., 2006; Earnheart et al., 2007; Bortone \& Polleux, 2009). Therefore, restoring GABA activity might normalize neurogenesis and different neuromorphological anomalies of the Ts65Dnbrain, leading to more efficient learning (Martinez-Cue et al., 2013).

\section{CONCLUDING REMARKS}

There is an unmet need to develop pharmacotherapies to improve the cognitive deficits and the quality of life of individuals with DS. Numerous studies in mouse models of DS have identified several potential targets for treatment. The demonstration of the role of GABA-mediated inhibition in the Ts65Dn mouse model of DS led to studies testing different antagonists that proved to be promnesic but might induce significant side effects.

Recent advances in the understanding of the physiology of the different $\mathrm{GABA}_{\mathrm{A}}$ receptor subunits have demonstrated the important modulatory role of $\mathrm{GABA}_{\mathrm{A}} \alpha 5$ subunit-containing receptors in cognition (Collinson et al., 2002; Crestani et al., 2002; Rudolph \& Knoflach, 2011), without inducing the unwanted effects produced by the activity of other subunits, which suggested the potential use of selective $\mathrm{GABA}_{\mathrm{A}} \alpha 5$ NAMs to enhance cognition in DS individuals. Different studies have recently demonstrated that diminishing $\mathrm{GABA}_{\mathrm{A}}$ inhibition in DS with NAMs selective for the $\alpha 5$-containing $\mathrm{GABA}_{\mathrm{A}}$ receptors appears to be a sensible strategy since two molecules of this class have already proven to be efficient for correcting 
cognitive deficits in DS mouse models and one is currently being tested in individuals with DS (Mohler, 2012) (http://clinicaltrials.gov/ct2/show/NCT01436955?term=rg1662\&rank=3).

Advances in teaching methods and education mainstreaming have proven beneficial for individuals with DS; however, these advances are not sufficient to improve all cognitive abilities. Interestingly, several studies in Ts65Dnmice have demonstrated the value of environmental enrichment in enhancing cognition (Martinez-Cue et al., 2002; Begenisic et al., 2011), hippocampal neurogenesis (Chakrabarti et al., 2010), and synaptic plasticity and decreasing GABAergic inhibition (Begenisic et al., 2011). Thus, a promising strategy would be to combine behavioral and pharmacological therapeutic strategies to try to maximize their benefits. In addition, several drugs have been shown to enhance cognition in the Ts65Dn mouse [i.e., fluoxetine (Bianchi et al., 2010b), lithium (Contestabile et al., 2012), different $\mathrm{GABA}_{\mathrm{B}}$ antagonists (Kleschevnikov et al., 2004; Kleschevnikov et al., 2012a; Kleschevnikov et al., 2012b), Shh agonists (Das et al., 2013), DYRK1a inhibitors, and melatonin (Altafaj et al., 2013; Corrales et al., 2013), among others]. Therefore, another strategy that should be explored is the efficacy of combining two or more of these drugs. In sum, these recent studies indicate the potential for development of new treatments to improve cognition in individuals with DS.

\section{ACKNOWLEDGMENTS}

The authors wish to thank the Agence Nationale de la Recherche (ANR Emmergence), the Spanish Ministry of Economy and Competitiveness (PSI2012-33652), and the Fondation Jérôme Lejeune for their financial support. 


\section{REFERENCES:}

Altafaj, X., Martin, E.D., Ortiz-Abalia, J., Valderrama, A., Lao-Peregrin, C., Dierssen, M. \& Fillat, C. (2013) Normalization of Dyrk1A expression by AAV2/1-shDyrk1A attenuates hippocampal-dependent defects in the Ts65Dn mouse model of Down syndrome. Neurobiol Dis, 52, 117-127.

Atack, J.R., Bayley, P.J., Seabrook, G.R., Wafford, K.A., McKernan, R.M. \& Dawson, G.R. (2006) L-655,708 enhances cognition in rats but is not proconvulsant at a dose selective for alpha5-containing GABAA receptors. Neuropharmacology, 51, 1023-1029.

Atack, J.R. (2010) Preclinical and clinical pharmacology of the GABA(A) receptor alpha5 subtype-selective inverse agonist alpha5IA. Pharmacol Ther, 125, 11-26.

Ballard, T.M., Knoflach, F., Prinssen, E., Borroni, E., Vivian, J.A., Basile, J., Gasser, R., Moreau, J.L., Wettstein, J.G., Buettelmann, B., Knust, H., Thomas, A.W., Trube, G. \& Hernandez, M.C. (2009a) RO4938581, a novel cognitive enhancer acting at $\mathrm{GABA}_{\mathrm{A}} \alpha 5$ subunit-containing receptors. Psychopharmacology, 202, 207-223.

Bartesaghi, R., Guidi, S. \& Ciani, E. (2011) Is it possible to improve neurodevelopmental abnormalities in Down syndrome? Rev Neurosci, 22, 419-455.

Begenisic, T., Spolidoro, M., Braschi, C., Baroncelli, L., Milanese, M., Pietra, G., Fabbri, M.E., Bonanno, G., Cioni, G., Maffei, L. \& Sale, A. (2011) Environmental enrichment decreases GABAergic inhibition and improves cognitive abilities, synaptic plasticity, and visual functions in a mouse model of Down syndrome. Front Cell Neurosci, 5, 29. 
Belichenko, P.V., Masliah, E., Kleschevnikov, A.M., Villar, A.J., Epstein, C.J., Salehi, A. \& Mobley, W.C. (2004) Synaptic structural abnormalities in the Ts65Dn mouse model of Down Syndrome. J Comp Neurol, 480, 281-298.

Belichenko, P.V., Kleschevnikov, A.M., Masliah, E., Wu, C., Takimoto-Kimura, R., Salehi, A. \& Mobley, W.C. (2009) Excitatory-inhibitory relationship in the fascia dentata in the Ts65Dn mouse model of Down syndrome. J Comp Neurol, 512, 453-466.

Best, T.K., Siarey, R.J. \& Galdzicki, Z. (2007) Ts65Dn, a mouse model of Down syndrome, exhibits increased GABAB-induced potassium current. J Neurophysiol, 97, 892-900.

Best, T.K., Cramer, N.P., Chakrabarti, L., Haydar, T.F. \& Galdzicki, Z. (2012) Dysfunctional hippocampal inhibition in the Ts65Dn mouse model of Down syndrome. Exp Neurol, 233, $749-757$.

Bhattacharyya, A., McMillan, E., Chen, S.I., Wallace, K. \& Svendsen, C.N. (2009) A critical period in cortical interneuron neurogenesis in down syndrome revealed by human neural progenitor cells. Dev Neurosci, 31, 497-510.

Bianchi, P., Ciani, E., Contestabile, A., Guidi, S. \& Bartesaghi, R. (2010a) Lithium restores neurogenesis in the subventricular zone of the Ts65Dn mouse, a model for Down syndrome. Brain Pathol, 20, 106-118.

Bianchi, P., Ciani, E., Guidi, S., Trazzi, S., Felice, D., Grossi, G., Fernandez, M., Giuliani, A., Calza, L. \& Bartesaghi, R. (2010b) Early pharmacotherapy restores neurogenesis and cognitive performance in the Ts65Dn mouse model for Down syndrome. $J$ Neurosci, 30, $8769-8779$. 
Bittles, A.H., Bower, C., Hussain, R. \& Glasson, E.J. (2007) The four ages of Down syndrome. Eur J Public Health, 17, 221-225.

Bonin, R.P., Martin, L.J., MacDonald, J.F. \& Orser, B.A. (2007) Alpha5GABAA receptors regulate the intrinsic excitability of mouse hippocampal pyramidal neurons. $J$ Neurophysiol, 98, 2244-2254.

Bonnert, T.P., McKernan, R.M., Farrar, S., le Bourdelles, B., Heavens, R.P., Smith, D.W., Hewson, L., Rigby, M.R., Sirinathsinghji, D.J., Brown, N., Wafford, K.A. \& Whiting, P.J. (1999) theta, a novel gamma-aminobutyric acid type A receptor subunit. Proc Natl Acad Sci U S A, 96, 9891-9896.

Bortone, D. \& Polleux, F. (2009) KCC2 expression promotes the termination of cortical interneuron migration in a voltage-sensitive calcium-dependent manner. Neuron, 62, $53-71$.

Braudeau, J., Dauphinot, L., Duchon, A., Loistron, A., Dodd, R.H., Herault, Y., Delatour, B. \& Potier, M.C. (2011a) Chronic Treatment with a Promnesiant GABA-A alpha5-Selective Inverse Agonist Increases Immediate Early Genes Expression during Memory Processing in Mice and Rectifies Their Expression Levels in a Down Syndrome Mouse Model. Adv Pharmacol Sci, 2011, 153218.

Braudeau, J., Delatour, B., Duchon, A., Pereira, P.L., Dauphinot, L., de Chaumont, F., OlivoMarin, J.C., Dodd, R.H., Herault, Y. \& Potier, M.C. (2011b) Specific targeting of the GABA-A receptor alpha5 subtype by a selective inverse agonist restores cognitive deficits in Down syndrome mice. J Psychopharmacol, 25, 1030-1042. 
Caraiscos, V.B., Elliott, E.M., You-Ten, K.E., Cheng, V.Y., Belelli, D., Newell, J.G., Jackson, M.F., Lambert, J.J., Rosahl, T.W., Wafford, K.A., MacDonald, J.F. \& Orser, B.A. (2004) Tonic inhibition in mouse hippocampal CA1 pyramidal neurons is mediated by alpha5 subunit-containing gamma-aminobutyric acid type A receptors. Proc Natl Acad Sci U S A, 101, 3662-3667.

Chakrabarti, L., Best, T.K., Cramer, N.P., Carney, R.S., Isaac, J.T., Galdzicki, Z. \& Haydar, T.F. (2010) Olig1 and Olig2 triplication causes developmental brain defects in Down syndrome. Nat Neurosci, 13, 927-934.

Chambers, M.S., Atack, J.R., Carling, R.W., Collinson, N., Cook, S.M., Dawson, G.R., Ferris, P., Hobbs, S.C., O'Connor, D., Marshall, G., Rycroft, W. \& Macleod, A.M. (2004) An orally bioavailable, functionally selective inverse agonist at the benzodiazepine site of GABAA alpha5 receptors with cognition enhancing properties. $J$ Med Chem, 47, 58295832.

Clark, S., Schwalbe, J., Stasko, M.R., Yarowsky, P.J. \& Costa, A.C. (2006) Fluoxetine rescues deficient neurogenesis in hippocampus of the Ts65Dn mouse model for Down syndrome. Exp Neurol, 200, 256-261.

Colas, D., Valletta, J.S., Takimoto-Kimura, R., Nishino, S., Fujiki, N., Mobley, W.C. \& Mignot, E. (2008) Sleep and EEG features in genetic models of Down syndrome. Neurobiol Dis, 30, $1-7$.

Colas, D., Chuluun, B., Warrier, D., Blank, M., Wetmore, D.Z., Buckmaster, P., Garner, C.C. \& Heller, H.C. (2013) Short-term treatment with the GABAA receptor antagonist pentylenetetrazole produces a sustained pro-cognitive benefit in a mouse model of Down's syndrome. Br J Pharmacol, 169, 963-973. 
Cole, S.O. (1986) Effects of benzodiazepines on acquisition and performance: a critical assessment. Neurosci Biobehav Rev, 10, 265-272.

Collinson, N., Kuenzi, F.M., Jarolimek, W., Maubach, K.A., Cothliff, R., Sur, C., Smith, A., Otu, F.M., Howell, O., Atack, J.R., McKernan, R.M., Seabrook, G.R., Dawson, G.R., Whiting, P.J. \& Rosahl, T.W. (2002) Enhanced learning and memory and altered GABAergic synaptic transmission in mice lacking the alpha 5 subunit of the GABAA receptor. J Neurosci, 22, 5572-5580.

Collinson, N., Atack, J.R., Laughton, P., Dawson, G.R. \& Stephens, D.N. (2006) An inverse agonist selective for alpha5 subunit-containing GABAA receptors improves encoding and recall but not consolidation in the Morris water maze. Psychopharmacology (Berl), 188, 619-628.

Contestabile, A., Greco, B., Ghezzi, D., Tucci, V., Benfenati, F. \& Gasparini, L. (2012) Lithium rescues synaptic plasticity and memory in Down syndrome mice. J Clin Invest, 123, 348-361.

Corrales, A., Martinez, P., Garcia, S., Vidal, V., Garcia, E., Florez, J., Sanchez-Barcelo, E.J., Martinez-Cue, C. \& Rueda, N. (2013) Long-term oral administration of melatonin improves spatial learning and memory and protects against cholinergic degeneration in middle-aged Ts65Dn mice, a model of Down syndrome. J Pineal Res, 54, 346-358.

Costa, A.C. \& Grybko, M.J. (2005) Deficits in hippocampal CA1 LTP induced by TBS but not HFS in the Ts65Dn mouse: a model of Down syndrome. Neurosci Lett, 382, 317-322. 
Costa, A.C., Scott-McKean, J.J. \& Stasko, M.R. (2008) Acute injections of the NMDA receptor antagonist memantine rescue performance deficits of the Ts65Dn mouse model of Down syndrome on a fear conditioning test. Neuropsychopharmacology, 33, 16241632.

Coussons-Read, M.E. \& Crnic, L.S. (1996) Behavioral assessment of the Ts65Dn mouse, a model for Down syndrome: altered behavior in the elevated plus maze and open field. Behav Genet, 26, 7-13.

Crestani, F., Keist, R., Fritschy, J.M., Benke, D., Vogt, K., Prut, L., Bluthmann, H., Mohler, H. \& Rudolph, U. (2002) Trace fear conditioning involves hippocampal alpha5 GABA(A) receptors. Proc Natl Acad Sci U S A, 99, 8980-8985.

Das, I., Park, J.M., Shin, J.H., Jeon, S.K., Lorenzi, H., Linden, D.J., Worley, P.F. \& Reeves, R.H. (2013) Hedgehog agonist therapy corrects structural and cognitive deficits in a Down syndrome mouse model. Sci Transl Med, 5, 201ra120.

Dawson, G.R., Maubach, K.A., Collinson, N., Cobain, M., Everitt, B.J., MacLeod, A.M., Choudhury, H.I., McDonald, L.M., Pillai, G., Rycroft, W., Smith, A.J., Sternfeld, F., Tattersall, F.D., Wafford, K.A., Reynolds, D.S., Seabrook, G.R. \& Atack, J.R. (2006) An inverse agonist selective for $\alpha 5$ subunit-containing $\mathrm{GABA}_{\mathrm{A}}$ receptors enhances cognition. J Pharmacol Exp Ther, 316, 1335-1345.

del Cerro, S., Jung, M. \& Lynch, G. (1992) Benzodiazepines block long-term potentiation in slices of hippocampus and piriform cortex. Neuroscience, 49, 1-6.

Dorow, R., Horowski, R., Paschelke, G. \& Amin, M. (1983) Severe anxiety induced by FG 7142, a beta-carboline ligand for benzodiazepine receptors. Lancet, 2, 98-99. 
Driscoll, L.L., Carroll, J.C., Moon, J., Crnic, L.S., Levitsky, D.A. \& Strupp, B.J. (2004) Impaired sustained attention and error-induced stereotypy in the aged Ts65Dn mouse: a mouse model of Down syndrome and Alzheimer's disease. Behav Neurosci, 118, 11961205.

Duka, T., Curran, H.V., Rusted, J.M. \& Weingartner, H.J. (1996) Perspectives on cognitive psychopharmacology research. Behav Pharmacol, 7, 401-410.

Earnheart, J.C., Schweizer, C., Crestani, F., Iwasato, T., Itohara, S., Mohler, H. \& Luscher, B. (2007) GABAergic control of adult hippocampal neurogenesis in relation to behavior indicative of trait anxiety and depression states. J Neurosci, 27, 3845-3854.

Eng, W., Atack, J.R., Bergstrom, M., Sanabria, S., Appel, L., Dawson, G.R., Sciberras, D., Hargreaves, R.J., Langstrom, B. \& Burns, H.D. (2010) Occupancy of human brain $\mathrm{GABA}(\mathrm{A})$ receptors by the novel alpha5 subtype-selective benzodiazepine site inverse agonist alpha5IA as measured using [(1)(1)C]flumazenil PET imaging. Neuropharmacology, 59, 635-639.

Escorihuela, R.M., Fernandez-Teruel, A., Vallina, I.F., Baamonde, C., Lumbreras, M.A., Dierssen, M., Tobena, A. \& Florez, J. (1995) A behavioral assessment of Ts65Dn mice: a putative Down syndrome model. Neurosci Lett, 199, 143-146.

Escorihuela, R.M., Vallina, I.F., Martinez-Cue, C., Baamonde, C., Dierssen, M., Tobena, A., Florez, J. \& Fernandez-Teruel, A. (1998) Impaired short- and long-term memory in Ts65Dn mice, a model for Down syndrome. Neurosci Lett, 247, 171-174. 
Faizi, M., Bader, P.L., Tun, C., Encarnacion, A., Kleschevnikov, A., Belichenko, P., Saw, N., Priestley, M., Tsien, R.W., Mobley, W.C. \& Shamloo, M. (2011) Comprehensive behavioral phenotyping of Ts65Dn mouse model of Down syndrome: activation of beta1-adrenergic receptor by xamoterol as a potential cognitive enhancer. Neurobiol Dis, 43, 397-413.

Fernandez, F., Morishita, W., Zuniga, E., Nguyen, J., Blank, M., Malenka, R.C. \& Garner, C.C. (2007) Pharmacotherapy for cognitive impairment in a mouse model of Down syndrome. Nat Neurosci, 10, 411-413.

Fritschy, J.M. \& Mohler, H. (1995) GABAA-receptor heterogeneity in the adult rat brain: differential regional and cellular distribution of seven major subunits. J Comp Neurol, 359, 154-194.

Ge, S., Goh, E.L., Sailor, K.A., Kitabatake, Y., Ming, G.L. \& Song, H. (2006) GABA regulates synaptic integration of newly generated neurons in the adult brain. Nature, 439, 589593.

Ghoneim, M.M. \& Mewaldt, S.P. (1990) Benzodiazepines and human memory: a review. Anesthesiology, 72, 926-938.

Glykys, J. \& Mody, I. (2006) Hippocampal network hyperactivity after selective reduction of tonic inhibition in GABA A receptor alpha5 subunit-deficient mice. J Neurophysiol, $\mathbf{9 5}$, 2796-2807.

Guzowski, J.F., Timlin, J.A., Roysam, B., McNaughton, B.L., Worley, P.F. \& Barnes, C.A. (2005) Mapping behaviorally relevant neural circuits with immediate-early gene expression. Curr Opin Neurobiol, 15, 599-606. 
Hanson, J.E., Blank, M., Valenzuela, R.A., Garner, C.C. \& Madison, D.V. (2007) The functional nature of synaptic circuitry is altered in area CA3 of the hippocampus in a mouse model of Down's syndrome. J Physiol, 579, 53-67.

Haydar, T.F. \& Reeves, R.H. (2012) Trisomy 21 and early brain development. Trends Neurosci, 35, 81-91.

Holtzman, D.M., Santucci, D., Kilbridge, J., Chua-Couzens, J., Fontana, D.J., Daniels, S.E., Johnson, R.M., Chen, K., Sun, Y., Carlson, E., Alleva, E., Epstein, C.J. \& Mobley, W.C. (1996) Developmental abnormalities and age-related neurodegeneration in a mouse model of Down syndrome. Proc Natl Acad Sci U S A, 93, 13333-13338.

Huang, W., Galdzicki, Z., van Gelderen, P., Balbo, A., Chikhale, E.G., Schapiro, M.B. \& Rapoport, S.I. (2000) Brain myo-inositol level is elevated in Ts65Dn mouse and reduced after lithium treatment. Neuroreport, 11, 445-448.

Insausti, A.M., Megias, M., Crespo, D., Cruz-Orive, L.M., Dierssen, M., Vallina, I.F., Insausti, R. \& Florez, J. (1998) Hippocampal volume and neuronal number in Ts65Dn mice: a murine model of Down syndrome. Neurosci Lett, 253, 175-178.

Jensen, S., Kirkegaard, L. \& Anderson, B.N. (1987) Randomized clinical investigation of Ro 15-1788, a benzodiazepine antagonist, in reversing the central effects of flunitrazepam. Eur J Anaesthesiol, 4, 113-118.

Klausberger, T. (2009) GABAergic interneurons targeting dendrites of pyramidal cells in the CA1 area of the hippocampus. Eur J Neurosci, 30, 947-957. 
Kleschevnikov, A.M., Belichenko, P.V., Faizi, M., Jacobs, L.F., Htun, K., Shamloo, M. \& Mobley, W.C. (2012a) Deficits in cognition and synaptic plasticity in a mouse model of Down syndrome ameliorated by GABAB receptor antagonists. J Neurosci, 32, 92179227.

Kleschevnikov, A.M., Belichenko, P.V., Gall, J., George, L., Nosheny, R., Maloney, M.T., Salehi, A. \& Mobley, W.C. (2012b) Increased efficiency of the GABAA and GABAB receptor-mediated neurotransmission in the Ts65Dn mouse model of Down syndrome. Neurobiol Dis, 45, 683-691.

Kleschevnikov, A.M., Belichenko, P.V., Villar, A.J., Epstein, C.J., Malenka, R.C. \& Mobley, W.C. (2004) Hippocampal long-term potentiation suppressed by increased inhibition in the Ts65Dn mouse, a genetic model of Down syndrome. J Neurosci, 24, 8153-8160.

Krivanek, J. \& McGaugh, J.L. (1968) Effects of pentylenetetrazol on memory storage in mice. Psychopharmacologia, 12, 303-321.

Krivanek, J.A. (1971) Facilitation of avoidance learning by pentylenetetrazol as a function of task difficulty, deprivation and shock level. Psychopharmacologia, 20, 213-229.

Kurt, M.A., Kafa, M.I., Dierssen, M. \& Davies, D.C. (2004) Deficits of neuronal density in CA1 and synaptic density in the dentate gyrus, CA3 and CA1, in a mouse model of Down syndrome. Brain Res, 1022, 101-109.

Laurie, D.J., Wisden, W. \& Seeburg, P.H. (1992) The distribution of thirteen GABAA receptor subunit mRNAs in the rat brain. III. Embryonic and postnatal development. $J$ Neurosci, $12,4151-4172$. 
Lejeune, J., Turpin, R. \& Gautier, M. (1959) [Mongolism; a chromosomal disease (trisomy)]. Bull Acad Natl Med, 143, 256-265.

Lingford-Hughes, A., Hume, S.P., Feeney, A., Hirani, E., Osman, S., Cunningham, V.J., Pike, V.W., Brooks, D.J. \& Nutt, D.J. (2002) Imaging the GABA-benzodiazepine receptor subtype containing the alpha5-subunit in vivo with [11C]Ro15 4513 positron emission tomography. J Cereb Blood Flow Metab, 22, 878-889.

Lister, R.G. (1985) The amnesic action of benzodiazepines in man. Neurosci Biobehav Rev, 9, 87-94.

Little, H.J., Nutt, D.J. \& Taylor, S.C. (1984) Acute and chronic effects of the benzodiazepine receptor ligand FG 7142: proconvulsant properties and kindling. Br J Pharmacol, 83, 951-958.

Lott, I.T. \& Dierssen, M. (2010) Cognitive deficits and associated neurological complications in individuals with Down's syndrome. Lancet Neurol, 9, 623-633.

Macdonald, R.L. \& Olsen, R.W. (1994) GABAA receptor channels. Annu Rev Neurosci, 17, 569-602.

Martinez-Cue, C., Baamonde, C., Lumbreras, M., Paz, J., Davisson, M.T., Schmidt, C., Dierssen, M. \& Florez, J. (2002) Differential effects of environmental enrichment on behavior and learning of male and female Ts65Dn mice, a model for Down syndrome. Behav Brain Res, 134, 185-200. 
Martinez-Cue, C., Rueda, N., Garcia, E. \& Florez, J. (2006) Anxiety and panic responses to a predator in male and female Ts65Dn mice, a model for Down syndrome. Genes Brain Behav, 5, 413-422.

Martinez-Cue, C., Martinez, P., Rueda, N., Vidal, R., Garcia, S., Vidal, V., Corrales, A., Montero, J.A., Pazos, A., Florez, J., Gasser, R., Thomas, A.W., Honer, M., Knoflach, F., Trejo, J.L., Wettstein, J.G. \& Hernandez, M.C. (2013) Reducing GABAA alpha5 receptor-mediated inhibition rescues functional and neuromorphological deficits in a mouse model of down syndrome. $J$ Neurosci, 33, 3953-3966.

McNamara, R.K., dePape, G.E. \& Skelton, R.W. (1993) Differential effects of benzodiazepine receptor agonists on hippocampal long-term potentiation and spatial learning in the Morris water maze. Brain Res, 626, 63-70.

Menendez, M. (2005) Down syndrome, Alzheimer's disease and seizures. Brain Dev, 27, 246252.

Merschman, S.A., Rose, M.J., Pearce, G.E., Woolf, E.J., Schaefer, B.H., Huber, A.C., Musson, D.G., Perry, K.J., Rush, D.J., Varsolona, R.J. \& Matuszewski, B.K. (2005) Characterization of the solubility of a poorly soluble hydroxylated metabolite in human urine and its implications for potential renal toxicity. Pharmazie, 60, 359-363.

Mitra, A., Blank, M. \& Madison, D.V. (2012) Developmentally altered inhibition in Ts65Dn, a mouse model of Down syndrome. Brain Res, 1440, 1-8.

Mohler, H., Fritschy, J.M., Luscher, B., Rudolph, U., Benson, J. \& Benke, D. (1996) The GABAA receptors. From subunits to diverse functions. Ion Channels, 4, 89-113. 
Mohler, H. (2012) Cognitive enhancement by pharmacological and behavioral interventions: the murine Down syndrome model. Biochem Pharmacol, 84, 994-999.

Nutt, D.J., Besson, M., Wilson, S.J., Dawson, G.R. \& Lingford-Hughes, A.R. (2007) Blockade of alcohol's amnestic activity in humans by an alpha5 subtype benzodiazepine receptor inverse agonist. Neuropharmacology, 53, 810-820.

Olsen, R.W., Bureau, M., Khrestchatisky, M., MacLennan, A.J., Chiang, M.Y., Tobin, A.J., Xu, W., Jackson, M., Sternini, C. \& Brecha, N. (1990) Isolation of pharmacologically distinct GABA-benzodiazepine receptors by protein chemistry and molecular cloning. Adv Biochem Psychopharmacol, 46, 35-49.

Olsen, R.W. \& Sieghart, W. (2009) GABA A receptors: subtypes provide diversity of function and pharmacology. Neuropharmacology, 56, 141-148.

Perez-Cremades, D., Hernandez, S., Blasco-Ibanez, J.M., Crespo, C., Nacher, J. \& Varea, E. (2010) Alteration of inhibitory circuits in the somatosensory cortex of Ts65Dn mice, a model for Down's syndrome. J Neural Transm, 117, 445-455.

Petersen, E.N., Jensen, L.H., Honore, T. \& Braestrup, C. (1983) Differential pharmacological effects of benzodiazepine receptor inverse agonists. Adv Biochem Psychopharmacol, $38,57-64$.

Pueschel, S.M., Louis, S. \& McKnight, P. (1991) Seizure disorders in Down syndrome. Arch Neurol, 48, 318-320.

Rabow, L.E., Russek, S.J. \& Farb, D.H. (1995) From ion currents to genomic analysis: recent advances in GABAA receptor research. Synapse, 21, 189-274. 
Reeves, R.H., Irving, N.G., Moran, T.H., Wohn, A., Kitt, C., Sisodia, S.S., Schmidt, C., Bronson, R.T. \& Davisson, M.T. (1995) A mouse model for Down syndrome exhibits learning and behaviour deficits. Nat Genet, 11, 177-184.

Reynolds, G.P. \& Warner, C.E. (1988) Amino acid neurotransmitter deficits in adult Down's syndrome brain tissue. Neurosci Lett, 94, 224-227.

Ross, M.H., Galaburda, A.M. \& Kemper, T.L. (1984) Down's syndrome: is there a decreased population of neurons? Neurology, 34, 909-916.

Rudolph, U. \& Knoflach, F. (2011) Beyond classical benzodiazepines: novel therapeutic potential of GABAA receptor subtypes. Nat Rev Drug Discov, 10, 685-697.

Rudolph, U. \& Mohler, H. (2006) GABA-based therapeutic approaches: GABAA receptor subtype functions. Curr Opin Pharmacol, 6, 18-23.

Rueda, N., Mostany, R., Pazos, A., Florez, J. \& Martinez-Cue, C. (2005) Cell proliferation is reduced in the dentate gyrus of aged but not young Ts65Dn mice, a model of Down syndrome. Neurosci Lett, 380, 197-201.

Rueda, N., Florez, J. \& Martinez-Cue, C. (2008) Chronic pentylenetetrazole but not donepezil treatment rescues spatial cognition in Ts65Dn mice, a model for Down syndrome. Neurosci Lett, 433, 22-27.

Rueda, N., Florez, J. \& Martinez-Cue, C. (2012) Mouse models of Down syndrome as a tool to unravel the causes of mental disabilities. Neural Plast, 2012, 584071. 
Salehi, A., Faizi, M., Colas, D., Valletta, J., Laguna, J., Takimoto-Kimura, R., Kleschevnikov, A., Wagner, S.L., Aisen, P., Shamloo, M. \& Mobley, W.C. (2009) Restoration of norepinephrine-modulated contextual memory in a mouse model of Down syndrome. Sci Transl Med, 1, 7ra17.

Saran, N.G., Pletcher, M.T., Natale, J.E., Cheng, Y. \& Reeves, R.H. (2003) Global disruption of the cerebellar transcriptome in a Down syndrome mouse model. Hum Mol Genet, 12, 2013-2019.

Sarter, M., Bruno, J.P. \& Berntson, G.G. (2001) Psychotogenic properties of benzodiazepine receptor inverse agonists. Psychopharmacology (Berl), 156, 1-13.

Savic, M.M., Clayton, T., Furtmuller, R., Gavrilovic, I., Samardzic, J., Savic, S., Huck, S., Sieghart, W. \& Cook, J.M. (2008) PWZ-029, a compound with moderate inverse agonist functional selectivity at $\mathrm{GABA}(\mathrm{A})$ receptors containing alpha5 subunits, improves passive, but not active, avoidance learning in rats. Brain Res, 1208, 150-159.

Seabrook, G.R., Easter, A., Dawson, G.R. \& Bowery, B.J. (1997) Modulation of long-term potentiation in CA1 region of mouse hippocampal brain slices by GABAA receptor benzodiazepine site ligands. Neuropharmacology, 36, 823-830.

Seidl, R., Cairns, N., Singewald, N., Kaehler, S.T. \& Lubec, G. (2001) Differences between GABA levels in Alzheimer's disease and Down syndrome with Alzheimer-like neuropathology. Naunyn Schmiedebergs Arch Pharmacol, 363, 139-145.

Serwanski, D.R., Miralles, C.P., Christie, S.B., Mehta, A.K., Li, X. \& De Blas, A.L. (2006) Synaptic and nonsynaptic localization of GABAA receptors containing the alpha5 subunit in the rat brain. J Comp Neurol, 499, 458-470. 
Sherman, S.L., Allen, E.G., Bean, L.H. \& Freeman, S.B. (2007) Epidemiology of Down syndrome. Ment Retard Dev Disabil Res Rev, 13, 221-227.

Siarey, R.J., Carlson, E.J., Epstein, C.J., Balbo, A., Rapoport, S.I. \& Galdzicki, Z. (1999) Increased synaptic depression in the Ts65Dn mouse, a model for mental retardation in Down syndrome. Neuropharmacology, 38, 1917-1920.

Siarey, R.J., Stoll, J., Rapoport, S.I. \& Galdzicki, Z. (1997) Altered long-term potentiation in the young and old Ts65Dn mouse, a model for Down Syndrome. Neuropharmacology, 36, 1549-1554.

Sieghart, W., Eichinger, A., Richards, J.G. \& Mohler, H. (1987) Photoaffinity labeling of benzodiazepine receptor proteins with the partial inverse agonist [3H]Ro 15-4513: a biochemical and autoradiographic study. Journal of neurochemistry, 48, 46-52.

Smigielska-Kuzia, J. \& Sobaniec, W. (2007) Brain metabolic profile obtained by proton magnetic resonance spectroscopy HMRS in children with Down syndrome. Adv Med Sci, 52 Suppl 1, 183-187.

Smigielska-Kuzia, J., Bockowski, L., Sobaniec, W., Kulak, W. \& Sendrowski, K. (2010) Amino acid metabolic processes in the temporal lobes assessed by proton magnetic resonance spectroscopy (1H MRS) in children with Down syndrome. Pharmacol Rep, 62, 10701077.

Sternfeld, F., Carling, R.W., Jelley, R.A., Ladduwahetty, T., Merchant, K.J., Moore, K.W., Reeve, A.J., Street, L.J., O'Connor, D., Sohal, B., Atack, J.R., Cook, S., Seabrook, G., Wafford, K., Tattersall, F.D., Collinson, N., Dawson, G.R., Castro, J.L. \& MacLeod, 
A.M. (2004) Selective, orally active gamma-aminobutyric acidA alpha5 receptor inverse agonists as cognition enhancers. J Med Chem, 47, 2176-2179.

Sturgeon, X. \& Gardiner, K.J. (2011) Transcript catalogs of human chromosome 21 and orthologous chimpanzee and mouse regions. Mamm Genome, 22, 261-271.

Szemes, M., Davies, R.L., Garden, C.L. \& Usowicz, M.M. (2013) Weaker control of the electrical properties of cerebellar granule cells by tonically active GABAA receptors in the Ts65Dn mouse model of Down's syndrome. Mol Brain, 6, 33 .

Tischmeyer, W. \& Grimm, R. (1999) Activation of immediate early genes and memory formation. Cell Mol Life Sci, 55, 564-574.

Tozuka, Y., Fukuda, S., Namba, T., Seki, T. \& Hisatsune, T. (2005) GABAergic excitation promotes neuronal differentiation in adult hippocampal progenitor cells. Neuron, 47, 803-815.

Veall, R.M. (1974) The prevalance of epilepsy among mongols related to age. J Ment Defic Res, 18, 99-106.

Venault, P., Chapouthier, G., Simiand, J., Dodd, R.H. \& Rossier, J. (1987) Enhancement of performance by methyl beta-carboline-3-carboxylate, in learning and memory tasks. Brain Res Bull, 19, 365-370.

Venault, P. \& Chapouthier, G. (2007) From the behavioral pharmacology of beta-carbolines to seizures, anxiety, and memory. ScientificWorldJournal, 7, 204-223. 
Whiting, P.J., Bonnert, T.P., McKernan, R.M., Farrar, S., Le Bourdelles, B., Heavens, R.P., Smith, D.W., Hewson, L., Rigby, M.R., Sirinathsinghji, D.J., Thompson, S.A. \& Wafford, K.A. (1999) Molecular and functional diversity of the expanding GABA-A receptor gene family. Ann N Y Acad Sci, 868, 645-653.

Whittle, N., Sartori, S.B., Dierssen, M., Lubec, G. \& Singewald, N. (2007) Fetal Down syndrome brains exhibit aberrant levels of neurotransmitters critical for normal brain development. Pediatrics, 120, e1465-1471.

Wishart, J.G. (2007) Socio-cognitive understanding: a strength or weakness in Down's syndrome? J Intellect Disabil Res, 51, 996-1005.

Yee, B.K., Hauser, J., Dolgov, V.V., Keist, R., Mohler, H., Rudolph, U. \& Feldon, J. (2004) GABA receptors containing the alpha5 subunit mediate the trace effect in aversive and appetitive conditioning and extinction of conditioned fear. Eur J Neurosci, 20, 19281936. 


\begin{tabular}{|c|c|c|c|c|c|c|}
\hline & $\alpha 1$ & $\alpha 2$ & $\alpha 3$ & $\alpha 4$ & $\alpha 5$ & $\alpha 6$ \\
\hline \multicolumn{7}{|l|}{$\overline{\mathbf{K}_{\mathbf{i}}}$} \\
\hline$\alpha 5 \mathrm{IA}$ & $0.88 \mathrm{nM}$ & $0.58 \mathrm{nM}$ & $0.61 \mathrm{nM}$ & $60 \mathrm{nM}$ & $0.66 \mathrm{nM}$ & $418 \mathrm{nM}$ \\
\hline RO493858 & $174 \mathrm{nM}$ & $185 \mathrm{nM}$ & $80 \mathrm{nM}$ & ND & $4.6 \mathrm{nM}$ & ND \\
\hline \multicolumn{7}{|c|}{ \% GABA response $\left(\mathrm{EC}_{20}\right)$} \\
\hline $\begin{array}{l}\alpha 5 \mathrm{IA} 30 \mathrm{nM} \\
\text { rat } \\
\text { human }\end{array}$ & $\begin{array}{l}-4 \\
-5\end{array}$ & +12 & $\begin{array}{l}+4 \\
+15\end{array}$ & $\begin{array}{l}\text { ND } \\
\text { ND }\end{array}$ & $\begin{array}{l}-2 \\
-29\end{array}$ & $\begin{array}{l}\text { ND } \\
\text { ND }\end{array}$ \\
\hline RO4938581 $10 \mathrm{nM}$ & 0 to -10 & 0 to -10 & 0 to -10 & ND & -30 & ND \\
\hline
\end{tabular}

Table 1: Specificity profile of the NAMs $\alpha 5 \mathrm{IA}$ and RO4938581 for the various $\mathrm{GABA}_{\mathrm{A}}$ subunits. $\mathbf{K}_{\mathbf{i}}$ : inhibition of $\left[\mathrm{H}^{3}\right]$ flumazenil binding in mouse L(tk-) fibroblasts ( $\alpha 5$ IA) or HEK293 cells (RO4938581) expressing the $\alpha_{x} \beta_{3} \gamma_{2}$ ( $\alpha 5$ IA) or the $\alpha_{1} \beta_{2} \gamma_{2}, \alpha_{2} \beta_{3} \gamma_{2}, \alpha_{3} \beta_{3} \gamma_{2}$ or $\alpha_{5} \beta_{3} \gamma_{2}$ (RO493858) subunits of $\mathrm{GABA}_{\mathrm{A}}$ receptors. $\mathrm{Ki}=\mathrm{IC} 50 /\left(1+([\right.$ radioligand $] / \mathrm{KD})$. Modulation of the $\mathrm{GABA} \mathrm{EC}_{20^{-}}$ evoked current in different subtypes of recombinant human and rat $\mathrm{GABA}_{\mathrm{A}}$ receptors in HEK293 cells (both compounds) (Sternfeld et al., 2004; Ballard et al., 2009). 


\begin{tabular}{|l|c|c|}
\hline \multicolumn{2}{|c|}{ Cognitive-enhancing effects } \\
\hline \multicolumn{2}{|c|}{ Side effects } \\
\hline MWM acquisition & $\nearrow$ & $\nearrow$ \\
\hline MWM retention & $=$ & $\nearrow$ \\
\hline MWM thigmotaxis & $\searrow$ & $\searrow$ \\
\hline \multicolumn{2}{|c|}{ RO4938581 } \\
\hline Anxiety in the open field & $\searrow$ & $\searrow$ \\
\hline Anxiety in the plus-maze & ND & $\searrow$ \\
\hline Hyperactivity in the hole board & $\searrow$ & $\searrow$ \\
\hline Hyperactivity in the plus-maze & & $\searrow$ \\
\hline
\end{tabular}

Table 2: Promnesiant and side effects of the NAMs $\alpha 5$ IA and RO4938581 in Ts65Dn mice (Braudeau et al., 2011; Martinez-Cue et al., 2013). ND: not determined; = no effect; $\nearrow$ and $\searrow$ of performances, respectively. 